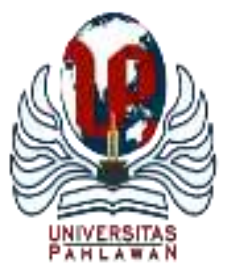

Edukatif : Jurnal Ilmu Pendidikan Volume 3 Nomor 6 Tahun 2021 Halm 4944 - 4951

EDUKATIF: JURNAL ILMU PENDIDIKAN

Research \& Learning in Education

https://edukatif.org/index.php/edukatif/index

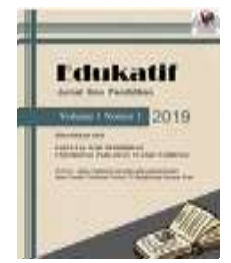

\title{
Kisah Nabi dan Rosul sebagai Upaya Penanaman Budaya Literasi pada Anak Usia Dini untuk Mencegah Problem Etik Digital
}

\author{
Nur Dwi Sukmono ${ }^{1 凶}$, Wening Sekar Kusuma ${ }^{2}$ \\ STKIP Modern Ngawi, Indonesia ${ }^{1,2}$ \\ E-mail : nd.sukmono92@gmail.com ${ }^{1}$, weningsekar13@ gmail.com $^{2}$
}

\begin{abstract}
Abstrak
Terdapat dampak positif dan negatif dalam penggunaan literasi digital. Dampak positifnya tentu sangat baik. Dampak negatif dari penggunaan media sosial yaitu, 1) Bullying, 2) pemicu kejahatan, 3) Pornografi, 4) Ancaman ujaran kebencian, dan 5) Perkembangan emosi. Berdasarkan hal tersebut, tentu penerapak pembelajaran literasi digital sangat penting. Dalam menyongsong program pemerintah, Gerakan Literasi Sekolah, maka sudah sepantasnya pihak sekolah berfokus pada pembelajaran literasi, terutama pada anak usia dini. Mengingat, dalam tahap anak usia dini masih belum bisa baca dan tulis, maka pelaksanaan literasi sebatas pada bercerita. Sehingga, dengan menggunakan kisah nabi dan rosul sebagai upaya penanaman budaya literasi pada anak usia dini untuk mencegah problem etik digital. Metode yang digunakan adalah penelitian kualitatif dengan menggunakan analisis deskriptif analitis. Adapun tahap-tahap yang diterapkan dalam penelitian ini adalah sebagai berikut: 1) Mengumpulkan data-data tentang literasi, literasi digital, dan budaya literasi; 2. Mengkaji data pustaka yang berhubungan tetang nilai moral, kisah nabi dan perkembangan anak; 3. Merumuskan strategi pengembangan budaya literasi dalam menghadapai problem etik digital melalui kisah-kisah nabi. Hasil dari penelitian adalah kelima hal negatif dalam menggunakan media sosial yang mengarah pada literasi digital tersebut dapat diantisipasi dengan kisah-kisah nabi yang menjadikan tokoh Nabi dan Rosul sebagai sosok yang patut dicontoh dalam menjalani kehidupan sehari-hari.
\end{abstract}

Kata Kunci: Kisah Nabi dan Rosul, Budaya Literasi, Anak Usia Dini, Problem Etik Digital.

\begin{abstract}
There are positive and negative impacts on the use of digital literacy. The positive impact is certainly very good. The negative impacts of using social media are, 1) Bullying, 2) triggering crime, 3) Pornography, 4) Threats of hate speech, and 5) Emotional development. Based on this, of course, implementing digital literacy learning is very important. In welcoming the government program, the School Literacy Movement, it is appropriate for schools to focus on literacy learning, especially in early childhood. Considering that in the early childhood stage they still cannot read and write, the implementation of literacy is limited to telling stories. So, using the story of the prophet and Rasul is an effort to instill a literacy culture in early childhood to prevent digital ethical problems. The method used is qualitative research using analytical descriptive analysis. The stages applied in this research are as follows: 1) Collecting data on literacy, digital literacy, and literacy culture; 2. Reviewing literature data related to moral values, prophet stories, and child development; 3. Formulate strategies for developing a literacy culture in dealing with digital ethical problems through the stories of the prophet. The results of this study are the five negative things in using social media that lead to digital literacy that can be anticipated with the stories of the prophets who make the figures of the Prophet and Rasul as figures who deserve to be emulated in living daily life. Keywords: The Story of the Prophet and Rasul, Literacy Culture, Early Childhood, Digital Ethical Problems.
\end{abstract}

Copyright (c) 2021 Nur Dwi Sukmono, Wening Sekar Kusuma

$\triangle$ Corresponding author:

Email : nd.sukmono92@gmail.com

DOI : https://doi.org/10.31004/edukatif.v3i6.1523

ISSN 2656-8063 (Media Cetak)

ISSN 2656-8071 (Media Online)

Edukatif : Jurnal Ilmu Pendidikan Vol 3 No 6 Tahun 2021 p-ISSN 2656-8063 e-ISSN 2656-8071 
4945 Kisah Nabi dan Rosul sebagai Upaya Penanaman Budaya Literasi pada Anak Usia Dini untuk Mencegah Problem Etik Digital - Nur Dwi Sukmono, Wening Sekar Kusuma

DOI: https://doi.org/10.31004/edukatif.v3i6.1523

\section{PENDAHULUAN}

Membaca merupakan langkah awal dalam membuka cakrawala pendidikan. Melalui membaca seseorang dapat memperluas pengetahuan dan memperdalam keilmuan. Membaca sudah menjadi bahan pokok untuk semua kalangan, bukan hanya kaum akademisi saja. Karena dengan membaca, itu berarti sudah menyeimbangkan antara kinerja otak dan otot. Menjaga kinerja neuron agar tetap aktif bekerja dapat mengatasi penyakit alzaimer.

Di dalam dunia pendidikan atau yang biasa disebut dengan akademisi, membaca merupakan pilar utama. Pengembangan metode, materi pembelajaran, hingga pengalaman orang lain mampu diperoleh melalui membaca. Suatu metode terbaik dapat ditemukan melalui literature-literatur baik berbentuk jurnal maupun media lainnya. Begitu juga dalam mengembangkan materi pembelajaran, pendidik dapat mengambil beberapa referensi yang sejenis sehingga mampu mengonversi berbagai materi menjadi suatu materi yang layak dan berguna bagi perkembangan.

Membaca bukan hanya sekedar reseptif bahasa tulis melainkan juga suatu kegiatan mengamati, mencermati, meneliti, dan mengambil pelajaran. Melalui membaca pandangan kita terhadap suatu hal menjadi lebih luas dan lebih teliti dalam mengambil suatu keputusan. Semakin luas bacaan seseorang, maka orang tersebut akan semakin bijak dalam mengambil langkah.

Melalui beberapa pemaparan di atas, tentu membaca merupakan suatu hal yang sangat penting dalam semua sisi kehidupan. Bukan hanya untuk kaum akademis saja melainkan juga orang umum. Namun, hingga saat ini minat baca di Indonesia cukup rendah. Dilansir dari World's Most Literate Nations Ranked yang dilakukan oleh Central Connecticut State Univesity tahun 2016, Indonesia dinyatakan menduduki peringkat ke-60 dari 61 negara soal minat membaca, persis berada di bawah Thailand (59) dan di atas Bostwana (61) (kominfo.go.id).

Namun disisi lain, Indonesia menduduki peringkat ke-5 dalam hal beropini di media social (Suara.com). Tentu hal ini merupakan paradoks dalam suatu leterasi. Dalam literasi tingkat membaca berbanding lurus dengan tingkatan menulis atau berbicara. Artinya, untuk meningkatkan keterampilan berbicara dan menulis maka dibutuhkan pengalaman membaca yang banyak. Jika hal tersebut tidak berbanding lurus, maka keterampilan berbicara dan menulis yang keluar adalah ujaran-ujaran tidak berbobot dan bahkan cenderung lebih sarkasme. Salah satu contohnya pada peristiwa All England 2021, netizen Indonesia menyerang habishabisan akun BWF, Federasi Bulu Tangkis Dunia (Kompas.com). Menurut pandangan media Internasional, Netizen Indonesia paling tidak sopan se-Asia.

Kualitas bacaan seseorang tentu dapat membantu seseorang dalam memilih kebenaran informasi. Terutama dalam era digitalisasi saat ini, penanaman literasi digital sangatlah penting untuk menghindari muatan-muatan hoax yang tersebar di berbagai media. Sebuah survey yang dilakukan oleh Mastel (2017 dalam Juditha, 2018) mengungkapkan bahwa dari 1.146 responden, 44,3\% diantaranya menerima berita hoax setiap hari dan $17,2 \%$ menerila lebih dari satu kali dalam sehari.

Berdasarkan data di atas, tentu membudayakan literasi sejak usia dini sangatlah penting. Tidak hanya untuk meningkatkan kecerdasan secara akademik, tapi lebih kepada mencerdaskan kehidupan bangsa terutama dalam era digitalisasi. Perkembangan teknologi sudah tidak bisa dibendung lagi sehingga bagaimanapun juga pendidikan di Indonesia harus segera membudayakan literasi. Sehingga, muncullah gerakan literasi pada setiap sekolah, walaupun secara penerapannya masih jauh panggang dari pada api.

Dari 34 provinsi di Indonesia, 9 provinsi $(26 \%)$ masuk dalam kategori aktivitas literasi sedang (angka indeks antara 40,01 - 60,00); 24 provinsi (71\%) masuk kategori rendah (20,01-40,00); dan 1 provinsi (3\%) masuk kategori sangat rendah $(0-20,00)$. Artinya sebagian besar provinsi berada pada level aktivitas literasi rendah dan tidak satu pun provinsi termasuk ke dalam level aktivitas literasi tinggi dan sangat tinggi (nilai indeks antara 60,01 - 80,00 dan 80,01 - 100,00) (Pusat Penelitian Kebijakan Pendidikan dan Kebudayaan, 
4946 Kisah Nabi dan Rosul sebagai Upaya Penanaman Budaya Literasi pada Anak Usia Dini untuk Mencegah Problem Etik Digital - Nur Dwi Sukmono, Wening Sekar Kusuma

DOI: https://doi.org/10.31004/edukatif.v3i6.1523

2019). Berdasarkan data tersebut dapat ditarik kesimpulan bahwa penerapan literasi di sekolah masih sangat kurang. Bahkan tidak ada satu provinsi pun yang berkategori tinggi atau bahkan sangat tinggi.

Namun, jika mengamati dari hasil survey yang dilakukan oleh Kominfo terkait literasi digital, angkanya sangat luar biasa, yakni 73,3\% atau sekitar 196,71 juta pengguna dari seluruh penduduk di Indonesia (Siaran Pers No. 149/HM/KOMINFO/11/2020). Tentu data tersebut sangat menggembirakan. Disamping penerapan literasi secara konvensional masih sangat kurang, ternyata berkebalikan jika secara digital.

Sayangnya, keunggulan dalam literasi digital tersebut tidaklah semuanya positif, karena dalam literasi digital terdapat berbagai media social juga seperti facebook, tweeter, youtube, dan masih banyak lagi yang tentunya terdapat literasi-literasi yang kurang pantas untuk dirawat. Maka, angka 73,3\% tersebut justru bisa menjadi bumerang bagi masyarakat itu sendiri, terutama dalam koridor pendidikan.

Dalam sebuah jurnal penelitian mengungkapkan pengaruh literasi digital terhadap psikologi anak dan remaja. Terdapat lima bentuk psikologi remaja namun dalam kasus literasi digital ini yang sering muncul adalah tiga, yakni Ingratiation, Intimidation, dan Supplication. Dari tiga hal tersebut menghasilkan rata-rata secara berurutan $34,2 \%, 64,61 \%$, dan 2,2\%. Kesimpulannya, dikarenakan rendahnya pemahaman terhadap literasi digital sehingga mengakibatkan anak dan remaja menjadi kehilangan identitas (Pratiwi \& Nola, 2019).

Beberapa kasus literasi digital yang paling ramai diberbincangkan adalah maraknya ujaran kebencian atau sarkasme warganet dari Indonesia. Ujaran kebencian warganet Indonesia bahkan sangatlah tinggi. Dalam riset yang dirilis oleh Microsoft ini, tingkat kesopanan netizen Indonesia memburuk delapan poin ke angka 76, di mana semakin tinggi angkanya tingkat kesopanan semakin buruk. Dilakukan survei pada 16.000 responden di 32 wilayah dalam jangka waktu April hingga Mei 2020. Hasilnya, warganet yang kurang sopan dan beberapa hal negatif seperti berita bohong dan ujaran kebencian masih banyak ditemukan (Kompas.com).

Penggunaan media sosial memang sangat mendominasi ujaran kebencian warganet. Sebuah jurnal mengkaji bahwa dalam penggunaan sosial media, terutama Youtube, masih ditemui penggunaan sarkasme. Dengan menggunakan metode deskriptif kualitatif, peneliti menemukan aspek-aspek pelanggaran kesantunan berbahasa, baik dalam praliterasi maupun postliterasi. Peneliti beranggapan bahwa penggunaan sarkasme pada media sosial cenderung lebih banyak dijumpai dibandingkan dengan aktivitas sehari-hari (Sukmono, 2020).

Selain pada remaja, sosial media juga digunakan pada anak. Adapun dampak negatif dari penggunaan sosial media yaitu: 1) Bullying, 2) pemicu kejahatan, 3) Pornografi, 4) Ancaman ujaran kebencian, dan 5) Perkembangan emosi. Komunikasi buruk pada anak diakibatkan karena interaksi dengan orang lain yang semakin berkurang atau bahkan tidak berhubungan sama sekali dengan masyarakat sekitar (Sunarto, $\mathrm{PhD}$, 2017).

Dalam menyongsong program pemerintah, Gerakan Literasi Sekolah, maka sudah sepantasnya pihak sekolah berfokus pada pembelajaran literasi, terutama pada anak usia dini. Mengingat, dalam tahap anak usia dini masih belum bisa baca dan tulis, maka pelaksanaan literasi sebatas pada bercerita.

Selain meningkatkan ketertarikan anak terhadap budaya literasi, bercerita juga harusnya mampu mengangkat karakter-karakter baik dalam setiap kisahnya. Maka, dibutuhkan cerita-cerita yang memiliki nilainilai karakter yang berbudi luhur. Karena selain literasi, penanaman moral terhadap anak usia dini sangat penting.

\section{METODE PENELITIAN}

Penelitian ini menggunakan metode deskriptif kualitatif dengan melakukan studi pustaka. Pelaksanaan metode ini dengan mengumpulkan data informasi dari berbagai sumber referensi yang ada di perpustakaan. Referensi yang digunakan meliputi buku, jurnal, dan media massa digital. Pendekatan yang digunakan adalah penelitian kualitatif dengan menggunakan analisis deskriptif analitis (Sugiyono, 2013). Adapun tahap-tahap yang diterapkan dalam penelitian ini adalah sebagai berikut: 
4947 Kisah Nabi dan Rosul sebagai Upaya Penanaman Budaya Literasi pada Anak Usia Dini untuk Mencegah Problem Etik Digital - Nur Dwi Sukmono, Wening Sekar Kusuma

DOI: https://doi.org/10.31004/edukatif.v3i6.1523

1. Mengumpulkan data-data yang diperoleh dari berbagai sumber pustaka yang berhubungan tentang literasi, literasi digital, dan budaya literasi

2. Mengkaji data pustaka yang berhubungan tetang karakter, kisah nabi dan perkembangan anak.

3. Merumuskan strategi pengembangan budaya literasi dalam menghadapai problem etik digital melalui kisah-kisah nabi.

\section{HASIL DAN PEMBAHASAN PENELITIAN}

Perkembangan teknologi di bidang teknologi informasi membuat perubahan besar dalam hal teknologi, dalam hal ini adalah digitalisasi. Konsep media cetak dan elektronik dapat digabungkan dan didistribusikan (Tamburaka, 2013:72). Dengan berkembangnya teknologi informasi berkembanglah pula konsep komunikasi verbal yang berbentuk digital. Hal ini tentu memerlukan telaah lebih mendalam, karena belum ada pelajaran tentang etik digital di bangku sekolah. Menurut Retnowati (2015: 314) literasi digital dikembangkan agar individu mampu memiliki pemikiran kritis dalam mengekpresikan diri dan berperan aktif dalam media. Maka, budaya literasi tentu akan bergeser kearah yang lebih kritis dalam era digitalisasi. Dengan demikian perlu pencegahan dengan menanamkan nilai-nilai yang terdapat dalam kisah nabi dan rosul.

\section{Bullying}

Berdasarkan etimologi kata bully bermakna penggertak, orang yang mengganggu orang lemah (Wiyani, 2012:12). Kegiatan bullying sangat sering sekali ditemukan dalam komunikasi digital. Bahkan tanpa sungkan mereka mengolok dengan ungkapan sarkas pada seseorang, menghakimi postingan atau tayangan seseorang dan masih banyak yang lainnya. Tentu hal semacam itu tidaklah tepat. Objek yang biasa dijadikan bullying adalah mengenai kehidupan personal atau pribadi seseorang, misalnya mengenai mode atau cara berpakaian, body enguageatau bentuk tubuh seseorang, kepemilikan suatu barang, hubungan asmara seseorang, dan lainlain. Ketidak sukaan seseorang ini selanjutnya diwujudkan dengan ucapan atau ejekan pada account media sosial yang dimiliki orang tersebut (Riswanto \& Marsinun, 2020).

Dalam kisah Nabi Muhammad SAW dan pengemis buta. Disitu digambarkan bahwa Rosul selalu dicaci maki dan dihina oleh seorang pengemis buta. Ia mencaci maki dan menghina dihadapan orang yang selalu menyuapi ia setiap pagi. Orang itu tak lain adalah Nabi Muhammad itu sendiri. Pada saat beliau dicaci dan dihina beliau hanya diam dan terus menyuapi. Hingga kemudian pengemis buta itu tahu bahwa yang selama ini menyuapi dia adalah Nabi Muhammad. Lalu ia pun bersedih.

Maka, pada dasarnya seseorang yang ada di dalam media sosial tidak tahu yang sebenarnya orang tersebut sebagai sosok yang seperti apa dan bagaimana. Hanya mengetahui keburukan-keburukan dari komentar yang sebelumnya tanpa mengetahui kebenarannya. Disini dapat diambil kesimpulan, bahwa jangan pernah jadi orang yang buta, terutama dalam bermedia sosial. Maksud dari kata buta adalah tidak mengetahui problem sebenarnya tapi ikut-ikutan bully. Adapun nilai lain dalam kisah tersebut, sebaiknya kita tetap berbuat baik terhadap sesame meskipun orang menghujat dan menganggap buruk diri kita. Jangan pernah membenci orang yang mencaci karena yang mengetahui diri seseorang yang seseorang itu sendiri.

Hal tersebut merupakan salah satu bentuk etika berkomunikasi secara digital. Dengan menahan diri dalam berkomentar dan mengetahui benar salah dahulu sebelum berkomentar dapat dikatakan sebagai salah satu bentuk kode etik. Setidaknya seseorang mampu mengetahui terlebih dahulu kekurangan dan kelebihan pada diri seseorang dahulu sebelum mengolok (Abdul Sakban, 2018).

\section{Pemicu Kejahatan}

Kejahatan merupakan suatu devian primer yang menimbulkan perbuatan melawan hukum dan devian sekunder terhadap suatu proses dimana orang lain beraksi terhadap akibat dari devian primer (J.E. Sahetapy, 2005: 32 dalam Angkupi, 2014). 
4948 Kisah Nabi dan Rosul sebagai Upaya Penanaman Budaya Literasi pada Anak Usia Dini untuk Mencegah Problem Etik Digital - Nur Dwi Sukmono, Wening Sekar Kusuma

DOI: https://doi.org/10.31004/edukatif.v3i6.1523

Kejahatan Digital adalah sebuah perbuatan yang tecela dan melanggar kepatutan di dalam kehidupan mayarakat serta melanggar hukum, sekalipun sampai sekarang sukar untuk menemukan norma hukum yang secara khusus mengatur kejahatan digital. Oleh karena itu peran masyarakat dalam upaya menegakan hukum terhadap kejahatan digital adalah penting untuk menentukan sifat dapat dicela dan melanggar kepatutan masyarakat dari suatu perbuatan kejahatan digital (Arief \& Gultom, 2005).

Dalam kisah Nabi Yusuf AS dan Saudaranya memiliki nilai tentang pemicu kejahatan. Dikisahkan bahwa Nabi Yusuf adalah anak kesayangan Nabi Yaqub dan hal tersebut membuat saudaranya iri terhadap Nabi Yusuf. Sehingga saudaranya berencana untuk mencelakai Nabi Yusuf. Tibalah hari tersebut, saudarasaudara Nabi Yusuf mengajaknya jalan-jalan. Nabi Yaqub mengizinkan. Sampailah mereka pada sebuah lading yang disekitarnya terdapat sumur. Kemudian saudara-saudara Nabi Yusuf memasukkannya kedalam sumur tersebut. Lalu mereka pulang sambil membawa sobekan baju Nabi Yusuf yang sudah dilumuri darah anjing agar Nabi Yaqub percaya bahwa Nabi Yusuf sudah dimakan oleh srigala.

Dari kisah tersebut kita dapat mempelajari bahwa kejahatan dapat muncul dari mana saja dan siapa saja. Dengan motif yang berbeda-beda dan dengan cara yang berbeda pula. Sehingga, dengan selalu meningkatkan kewaspadaan akan dapat mengurangi kejahatan, terutama kejahatan digital.

Berdasarkan data KPAI, ada 8 anak korban, 3 kasus anak korban pengeryokan, 3 kasus anak korban kekerasan seksual, 8 kasus anak korban kekerasan fisik, 12 kasus anak korban kekerasan psikis dan bullying serta kasus anak pelaku bullying terhadap guru. Akibat buruk dari media sosial tersebut tidak bisa dianggap remeh, karena apabila didiamkan terus menerus akan penyimpangan perilaku. Tidak mengherankan jika bahaya bahaya akibat media sosial sangatlah tinggi dikalangan remaja. Maka dibutuhkan filter dalam menggunakan media sosial agar dapat mengubah perilaku sosial dan mencegah tindakan kejahatan (Ikawati, 2018).

\section{Pornografi}

Pornografi adalah segala sesuatu yang bersifat seksual, khususnya yang dianggap berselera rendah atau tidak bermoral, apabila pembuatan, penyajian atau konsumsi bahan tersebut dimaksudkan hanya untuk membangkitkan rangsangan seksual (Haidar \& Apsari, 2020).

Dalam menggunakan media sosial, risiko mendapatkan perlakuan pornografi sangatlah tinggi. Tentu hal tersebut perlu diantisipasi terlebih dahulu sebelum seseorang mengalami, terutama pada kalangan perempuan. Karena objek yang paling dijaga sejak zaman nabi adam hingga sekarang adalah seorang wanita (Shofiyah, 2020).

Dalam kisah Nabi Yusuf AS dan Siti Zulaikah terdapat cerita yang bernilai antipornografi dan pencegahannya. Pada kisah tersebut diceritakan bahwa Siti Zulaikah sangat kagum akan ketampanannya Nabi Yusuf AS. Sehingga, itu membuat Siti Zulaikah sangat terpikat dan memunculkan hasrat seksualitasnya. Hingga akhirnya, Nabi Yusuf pun dijebak oleh Siti Zulaikah masuk di dalam rumahnya sendirian dan mengajak Nabi Yusuf untuk melakukan perbuatan yang tidak terpuji, tapi Nabi Yusuf menolak karena beliau masih memiliki Allah SWT.

Berdasarkan kisah tersebut yang menjadi objek seksualitas adalah Nabi Yusuf AS. Berbeda pada dunia saat ini, yang menjadi objek seksualitas adalah seorang wanita. Namun, tetap saja bisa kita petik nilainya. Pertama, Nabi Yusuf mampu mencegah hal-hal yang negatif pada dirinya dengan cara memperburuk dirinya berharap bahwa Siti Zulaikah tidak mau lagi, tapi ternyata beliau tetap memaksa. Kedua, Nabi Yusuf tidak merasa ingin mempertunjukkan dirinya dengan cara kabur hingga bajunya sobek. Dari dua hal tersebut, ada nilai yang bisa diambil, yakni sebagai seorang wanita patutnya tidak usah terlalu mengumbar aurat agar tidak terserang pornografi.

Pendidikan akan kepemilikan biologis antara laki-laki dan perempuan juga perlu diperkenalkan sejak dini, agar mereka tahu norma-norma kesusilaan yang pantas dan tidak pantas dipertontonkan. Sehingga, nantinya kejahatan pornografi dapat dicegah (Hanifah, 2013). 
4949 Kisah Nabi dan Rosul sebagai Upaya Penanaman Budaya Literasi pada Anak Usia Dini untuk Mencegah Problem Etik Digital - Nur Dwi Sukmono, Wening Sekar Kusuma

DOI: https://doi.org/10.31004/edukatif.v3i6.1523

\section{Ujaran Kebencian}

Ujaran kebencian adalah informasi yang diunggah dan/atau disebarluaskan melalui platform jejaring media sosial yang ditujukan untuk mendiskreditkan seseorang atau sekelompok orang, memuat penghinaan, pencemaran nama baik, penistaan, perbuatan tidak menyenangkan, provokasi, dan bersifat menghasut (Muannas \& Mansyur, 2020). Dalam hal ini, ujaran kebenceian dapat juga diartikan kesalahan dalam mengutarakan ucapan yang tidak seuai pada konteks. Karena Seseorang harus tahu posisi dia sedang berbicara dalam ruang publik yang seperti apa. Karena media sosial merupakan salah satu prinsip equality or camaraderie (kesamaan atau kesekawanan), maka daya persasifnya pun cukup kental. Public figure menjadi teladan dan percontohan, dalam hal ini adalah ujarannya (Sukmono, 2020).

Ujaran kebencian bertolak belakang dengan konsep kesantunan berbahasa sebagai indikator kecerdasan linguistik, sama halnya dengan etika berkomunikasi (Ningrum et al., 2019). Dalam hal etika berkomunikasi perlu adanya tata aturan yang perlu ditaati. Seperti halnya rambu-rambu yang ada di jalan raya, tentu dalam menggunakan media sosial juga memiliki rambu-rambu agar penggunaan media sosial terhindar dari ujaran kebencian.

Dalam kisah Nabi Musa AS dan Firaun yang kejam. Dikisahkan bahwa Firaun adalah raja yang sangat kejam. Tidak hanya itu, ia mengaku bahwa dirinya adalah Tuhan. Sehingga ia meminta rakyatnya menyembah dirinya seorang. Nabi Musa yang mengetahui itu tidak tinggal diam. Suatu ketika di daerah mesir terjadi musim paceklik. Tidak pernah turun hujan, bahkan sampai berbulan-bulan. Hingga persediaan air pun juga sudah habis. Firaun pun melakukan berbagai ritual yang pada akhirnya tetap tidak bisa menurunkan hujan. Akhirnya kebesaran Nabi Musa pun terdengar oleh Raja Firaun dan ia meminta kepada Nabi Musa untuk berdoa kepada Tuhannya, jika memang turun hujan maka Tuhanmu sangat sakti. Lalu Nabi Musa berdoa, seketika hujan turun. Namun, Firaun malah menuduhnya sebagai ahli sihir.

Dari situ dapat diambil nilai, bahwa dalam berkomunikasi dengan orang memang tidak semuanya memiliki etika yang baik. Etika yang baik saat berkomunikasi belum tentu dibalas dengan etika yang baik pula. Maka, hal tersebut bisa menjadi pelajaran bahwa setiap manusia memang memiliki sifat yang berbedabeda.

Tidak jauh berbeda dalam komunikasi digital, terkadang dalam menggunakan media sosial mereka sering tidak mampu memfilter apa yang mereka tulis, sehingga muncullah kata-kata yang kurang pantas untuk dibaca (Muannas \& Mansyur, 2020). Fakta menunjukkan bahwa ujaran kebencian dan hoaks terus mengalami peningkatan dari tahun 2018 - 2019 kasusnya naik 501 dari 3.901 (Kemkominfo, 2019 dalam Sukmono, 2021). Sehingga, perlu adanya pendidikan literasi sejak usia dini agar kedepannya mereka memiliki etika dalam bersosial media sosial.

\section{Perkembangan Emosi}

Emosi adalah perasaan atau afeksi yang timbul ketika seseorag sedang berada dalam suatu keadaan atau suatu interaksi yang dianggap penting baginya (Jahja, 2011: 188). Sedangkan menurut (Pangestuti, 2013) Emosi adalah ketika seseorang menunjukkan dan mengungkapkan perasaannya terhadap bentuk pengungkapan perasaan terhadap sesuatu peristiwa atau kejadian.

Menurut CEO RSPH Shirley Cramer (dalam Liputan 6.com) menyatakan bahwa Instagram dan Snapchat dapat menyebabkan kesejahteraan mental yang buruk pada remaja, yang pada akhirnya akan mengganggu proses kematangan emosi. Hasil penelitian lain yang dilakukan oleh American Psychological Association (APA) juga menunjukkan bahwa media sosial telah banyak membuat remaja stres yang pada akhirnya mempengaruhi keseluruhan kesehatan mentalnya. Stress dapat menganggu kestabilan emosi individu terutama pada remaja.

Remaja yang terlalu sering menggunakan sosial media maka kemungkinan dapat mengganggu kestabilan emosinya. Kondisi emosi remaja sendiri masih labil, sehingga belum dapat menempatkan emosi pada tempatnya. Individu cenderung melampiaskan emosi secara sembarang, seperti sering mengeluh, tiba- 
4950 Kisah Nabi dan Rosul sebagai Upaya Penanaman Budaya Literasi pada Anak Usia Dini untuk Mencegah Problem Etik Digital - Nur Dwi Sukmono, Wening Sekar Kusuma

DOI: https://doi.org/10.31004/edukatif.v3i6.1523

tiba moodnya berubah, yang awalnya senang berubah menjadi sedih disaat sering berinteraksi dengan temanteman sosial medianya (Utami, 2018). Kemudahan menrima respon dari seseorang membuat pribadi menjadi lebih instan dan tidak mudah menerima kenyataan. Karena, hal-hal yang ada di sosial media terkadang berbanding terbalik dengan apa yang ada di dunia nyata.

Dalam kisah Nabi Ismail AS ketika hendak disembelih oleh ayahnya yaitu Nabi Ibrahim AS. Ia secara sepontan menerima perintah tersebut dengan tenang dan bijaksana. Tidak mendramatisir ataupun melebihlebihkan. Karena Nabi Ismail yakin bahwa segala perintah dari Allah SWT pasti benar.

Sikap tenang dalam menghadapi berita yang tidak baik patut ditiru. Sikap tenang dapat membentuk kesetabilan emosi yang kemudian dapat memutuskan yang baik dan yang salah. Sikap tersebut sangat perlu dibangun sejak dini. Jangan sampai dibangun oleh media sosial yang akhirnya membuat anak cenderung tidak sabaran dan gegabah dalam bertindak.

Selain itu, kepeduliannya terhadap lingkungan juga sangatlah kurang. Mereka hanya akan berbuat jika ada yang memerintah alias tidak memiliki kesadaran sendiri akan lingkungan (Saniyyah et al., 2021). Tentu emosi perkembangan emosi yang seperti itu sangat bertolak belakang akan kultur yang sudah membudaya di Indonesia.

Kestabilan emosi adalah kemampuan individu dalam mengekspresikan emosinya untuk dapat mengatur stimulus yang berlebihan yang diterima dengan tepat dan tidak mudah mengalami perubahan emosi atau suasana hati dalam waktu cepat (Hurlock, 2002). Maka, dibutuhkan penanganan khusus dalam bersosial media. Literasi digital perlu diterapkan dengan mengambil contoh dari kisah-kisah nabi dan rosul.

Berdasarkan pemaparan di atas, dalam mengenalkan literasi digital, anak usia dini bisa diberikan pengalaman-pengalaman berdasarkan kisah-kisah nabi dan rosul. Agar nantinya dalam penggunaan literasi digital mereka dapat mengendalikan situasi dan mengurangi hal-hal negatif yang terdapat pada sosial media.

Kisah-kisah nabi dan rosul dapat diaplikasikan dalam bentuk apapun, bisa dalam bentuk video, ataupun berbentuk buku cerita. Cerita nabi dan rosul dapat menambah ketertarikan anak dalam membaca sehingga budaya literasi dapat dibentuk sekaligus pengetahuan tentang literasi digital juga dapat diberikan.

Cerita memiliki dampak yang besar terhadap pendengarnya. Anak-anak belajar dari berbagai tindakan kompleks dan agresif yang baru dengan mengamati perilaku yang ditunjukkan model. Akan muncul ingatan pada anak-anak termasuk kekerasan (tindakan agresi) dari model sampai enam bulan (Risdiany \& Lestari, 2021). Sedemikian efektif strategi bercerita atau membacakan kisah kepada anak hingga bisa dikatakan bahwa cerita dapat mempengaruhi kejayaan sebuah bangsa. Cerita atau kisah, bila dibacakan kepada anak dengan penuh kesungguhan akan memberi hasil yang luar biasa. Anak bisa terhipnotis oleh tokoh yang dikagumi dalam bacaan, sehingga ia melalui alam bawah sadarnya akan meniru dan mengidentifikasi segala yang ada dalam diri tokoh yang diidolakannya. Maka akan menjadi seperti apa seorang anak bisa dilihat dari apa yang dibacanya (Hibana, 2018).

\section{KESIMPULAN}

Dalam menerapkan literasi digital pada pembelajaran di sekolah tentu sebuah pilihan yang sangat sulit dilaksanakan. Media sosial seperti sebilah pisau yang memiliki peran positif dan negatif bergantung penggunaan. Budaya literasi perlu digalahkan terutma dalam bidang teknologi, mengingat peran teknologi kedapan pasti akan semakin canggih. Maka, literasi digital tidak akan terelakkan lagi partisipasinya. Sehingga perlu adanya trobosan baru terutama dalam mengenalkan literasi kepada Anak Usia Dini.

Pengantisipasian hal negatif literasi digital, yakni: 1) Bullying, 2) Kejahatan Digital, 3) Pornografi, 4) Ujaran Kebencian, dan 5) Perkembangan Emosi. Kelima hal tersebut dapat diantisipasi dengan menggunakan kisah-kisah nabi yang menjadikan tokoh Nabi dan Rosul sebagai sosok yang patut dicontoh dalam menjalani kehidupan sehari-hari. Sehingga, ketika mereka dewasa setidaknya akan meminimalisir pengaruh-pengaruh negatif dalam penggunaan media sosial dan mampu meningkatkan literasi digital. 
4951 Kisah Nabi dan Rosul sebagai Upaya Penanaman Budaya Literasi pada Anak Usia Dini untuk Mencegah Problem Etik Digital - Nur Dwi Sukmono, Wening Sekar Kusuma

DOI: https://doi.org/10.31004/edukatif.v3i6.1523

\section{DAFTAR PUSTAKA}

Angkupi, P. (2014). Kejahatan Melalui Media Sosial Elektronik di Indonesia Bedasarkan Peraturan Perundang-Undangan Saat Ini. Jurnal Mikrotik, 2(1), 1-8.

Haidar, G., \& Apsari, N. C. (2020). Pornografi Pada Kalangan Remaja. Prosiding Penelitian Dan Pengabdian Kepada Masyarakat, 7(1), 136. https://doi.org/10.24198/jppm.v7i1.27452

Hanifah, I. R. U. (2013). Kejahatan Pornografi Upaya Pencegahan dan Penanggulangannya di Kabupaten Ponorogo. Justicia Islamica, 10(2). https://doi.org/10.21154/justicia.v10i2.152

Hibana, H. (2018). Membangun Budaya Literasi Melalui Berkisah. ACIECE, 3, 293-304.

Hurlock, E. B. (2002). Perkembangan Anak Jilid 2 (Meitasari Tjandrasa. Terjemahan). Jakarta: Erlangga.

Ikawati, L. (2018). Pengaruh Media Sosial terhadap Tindak Kejahatan Remaja. Syariati : Jurnal Studi AlQur'an Dan Hukum, 4(02), 223-232. https://doi.org/10.32699/syariati.v4i02.1179

Juditha, C. (2018). Interaksi Komunikasi Hoax di Media Sosial Serta Antisipasinya. Journal Pekommas, 3(1), $31-34$

Muannas, M., \& Mansyur, M. (2020). Model Literasi Digital untuk Melawan Ujaran Kebencian di Media Sosial (Digital Literacy Model to Counter Hate Speech on Social Media). JURNAL IPTEKKOM (Jurnal Ilmu ..., 22(2), 125-142. https://jurnal.kominfo.go.id/index.php/iptekkom/article/viewFile/3378/1474

Ningrum, D. J., Suryadi, S., \& Chandra Wardhana, D. E. (2019). Kajian Ujaran Kebencian Di Media Sosial. Jurnal Ilmiah KORPUS, 2(3), 241-252. https://doi.org/10.33369/jik.v2i3.6779

Pangestuti, R. (2013). Psikologi perkembangan anak. Surakarta: Amelia Com.

Pratiwi, N., \& Nola, P. (2019). Pengaruh Literasi Digital terhadap Psikologis Anak dan Remaja Nani. Jurnal IIlmiah Program Studi Pendidikan Bahasa Dan Sastra Indonesia, 1-24.

Risdiany, H., \& Lestari, T. (2021). EDUKATIF: JURNAL ILMU PENDIDIKAN Pengaruh Film Kartun Upin Dan Ipin Terhadap Perkembangan Moral Anak. Edukatif: Jurnal Ilmu Pendidikan, 3(4), 13661372.

Riswanto, D., \& Marsinun, R. (2020). Perilaku Cyberbullying Remaja di Media Sosial. Analitika, 12(2), 98_ 111. https://doi.org/10.31289/analitika.v12i2.3704

Saniyyah, L., Setiawan, D., \& Ismaya, A. (2021). EDUKATIF : JURNAL ILMU PENDIDIKAN Dampak Penggunaan Gadget terhadap Perilaku Sosial Anak di Desa Jekulo Kudus. 3(4), 2132-2140.

Shofiyah. (2020). Dampak Media Sosial dan Pornografi Terhadap Perilaku Seks Bebas Anak di Bawah Umur. Alamtara: Jurnal Komunikasi Dan Penyiaran Islam, 4(1), 57-68.

https://ejournal.iai-tabah.ac.id/index.php/alamtaraok/article/download/503/373/

Sugiyono. (2013). Metode Penelitian Pendidikan Pendekatan Kuantitaif, Kualitatif, dan R\&DSugiyono. 2013. "Metode Penelitian Pendidikan Pendekatan Kuantitaif, Kualitatif, dan R\&D." Metode Penelitian Pendidikan Pendekatan Kuantitaif, Kualitatif, dan R\&D. https://doi.org/10.1. In Metode Penelitian Pendidikan Pendekatan Kuantitaif, Kualitatif, dan R\&D. https://doi.org/10.1007/s13398-014-0173-7.2

Sukmono, N. D. (2020). Sarkasme pada Post-Literasi dan Pra-Literasi dalam Media Youtube (Kanal Game Online ) Nur Dwi Sukmono. Jurnal Pendidikan Modern, 05(03), 102-103. https://doi.org/https://doi.org/10.37471/jpm.v5i3.90

Sukmono, N. D. (2021). Clickbait Judul Berita Online dalam Pemberitaan Covid-19. Transformatika: Jurnal Bahasa, Sastra, Dan Pengajarannya, 5(1), 1-13. https://doi.org/10.31002/transformatika.v

Sunarto, PhD, A. (2017). Dampak Media Sosial Terhadap Paham Radikalisme. Nuansa, 10(2), 89-99. https://doi.org/10.29300/nuansa.v10i2.647

Utami, C. D. (2018). Hubungan antara penggunaan sosial media dengan kestabilan emosi pada remaja. Jurnal Universitas 17 Agustus 1945 Surabaya, 1-7.

Edukatif : Jurnal Ilmu Pendidikan Vol 3 No 6 Tahun 2021 p-ISSN 2656-8063 e-ISSN 2656-8071 